\title{
INVOLVEMENT OF COMMUNITY MEMBERS IN SOLID WASTE MANAGEMENT AND ENVIRONMENTAL PROTECTION IN RIVERS STATE: IMPLICATIONS FOR SUSTAINABLE CITIES
}

\author{
Christiana Uzoaru Okorie (Ph. D) ${ }^{1 凹}$ (iD) \\ ${ }^{1}$ Department of Adult and Non-Formal Education, Faculty of Education, University of Port Harcourt, Nigeria
}

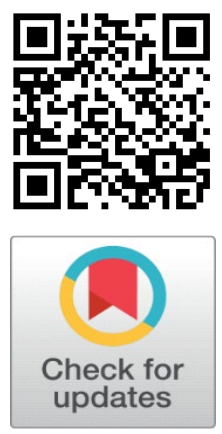

Received 5 December 2021

Accepted 15 December 2021

Published 31 January 2022

\section{CorrespondingAuthor}

Christiana Uzoaru Okorie, christiana.okorie@uniport.edu.ng

DOI

10.29121/granthaalayah.v10.i1.2022 4433

Funding: This research received no specific grant from any funding agency in the public, commercial, or not-for-profit sectors.

Copyright: (C) 2022 The Author(s). This is an open access article distributed under the terms of the Creative Commons Attribution License, which permits unrestricted use, distribution, and reproduction in any medium, provided the original author and source are credited.

\section{ABSTRACT}

The study is on the involvement of community members in solid waste management and environmental protection in Rivers State, its implications for sustainable cities. Waste management in Rivers State is surrounded with lots of set-back due to continual increase in population witness daily. More population creates room for generation of more waste which create the impression that Rivers State Waste Management Authority (RIWAMA) is not effective due to daily presence of littered waste in streets and major walkways in the state. To change this narrative for RIWAMA requires a more sustainable strategy through environmental education which is tailored towards change of negative waste management attitude to positive waste management among residents/dwellers because attitude reflects their waste disposal behaviour.

Keywords: Involvement, Community Members, Solid Waste, Solid Waste Management, Environmental Protection, Sustainable Cities.

\section{INTRODUCTION}

Waste management is one of the environmental issues that is of global concern due to it relatedness to human halt and environmental sustainability. Waste management to a high extent determines the wellness of people living in a particular place at any point in time because improper waste disposal constitute to favourable breeding grounds for vectors that transmit diseases to human. According to UNEP (2015, p.2) waste management is one of the essential utility services underpinning society in the 21st century, particularly in urban areas and that it is a basic human need and can also be regarded as a 'basic human right', (UNEP, 2015, p.2). Urban areas are prone to more waste generation due to human population in these areas, human are the ones that generate waste due to our production and consumption patterns. Several tonnes of waste especially solid waste are generated daily from household consumption in different cities all over the world. Kyte in Hoornweg and Bhada-Tata (2012) pointed out that cities in the world generate about 1.3 billion tonnes of solid waste per year and that the volume will probably increase to 2.2 billion tonnes by 2025 .

In Nigeria, waste generation and management has been of critical concern to government through the different agencies and ministries responsible for human health and the environment. At different state levels, there are days set aside in every week for market sanitation and also Saturdays set aside once in a month for monthly sanitation. For daily generated waste, each state through their sanitation agencies has different modalities they constitute to collect waste 
generated from households but despite all these modalities, the issue of indiscriminate disposal waste is still visible. It was as a result of the concern of indiscriminate waste disposal that are visible in most state of Nigeria that federal government in collaboration with World Bank and European Union Instituted waste management project that has youth empowerment scheme called State Employment and Expenditure for Results (SEEFOR). The overall objective of SEEFOR project as contained in Environmental and Social Management Plan (ESMP, 2015 ) is "to ensure employment generation through small public works and access to socio-economic services while improving the Public Financial Management system of participating States. This is tailored towards promoting accountability and transparency in the utilization of public finances which in turn translates into employment opportunities for the youths"

In Rivers State, the issue of managing waste has always been on the forefront of successive government. Government in Rivers State are conscious of maintaining the name "Garden City" in which Port Harcourt is known as through it waste management agency called Rivers State Waste Management Agency (RIWAMA). The Rivers State Waste Management Agency (RIWAMA) is a government of Rivers State body responsible for the enhancement of the environment with the aim of achieving positive and substantial change in living conditions as well as reducing diseases or health problems in the state. It was created in 2013 by the Rivers State House of Assembly and was assented by the state governor in July 2014. Prior to this, the agency had functioned as "Rivers State Environmental Sanitation Authority (RSESA)" which originally was formed in 1983 to tackle municipal waste and other related issues.

In other to keep Port Harcourt city and it environ clean, Rivers State Environmental Agency (RIWAMA) carry out different activities to keep Rivers State clean and maintain the garden city status. RIWAMA was birthed in 2013 to replace the former Rivers State Environmental Sanitation Authority (RSESA) through Rivers State Act of Parliament. RSEAS was formerly an autonomous government parastatal birthed in 1983 to manage municipal waste, public health, traffic and urban developmental challenges in Rivers State. With the replacement of RSEA with RIWAMA in 2014, the statutory responsibility of RIWAMA was reconstituted to be primarily responsible for maintaining a clean environment in all parts of Rivers State.

In order to compliment the work of RIWAMA towards waste management in Rivers State, federal government choose Rivers State as one of the fours sates in Nigeria that benefited from the federal government of Nigeria project of State Employment and Expenditure for Results (SEEFOR) which was piloted by the National Planning Commission (NPC) and the Federal Ministry of Finance. The project is financed through credit from the International Development Association (IDA), the World Bank (WB) and grant from the European Union (EU). Rivers State benefited from the credit and grant provided by federal government through the donor agencies (World Bank and European Union) for the purpose of promoting proper sanitation and hygiene in Rivers State.

The sanitation programme was intended to cover refuse collection and disposal at designated dumping sites, desilting and fumigation of drainages, road sweeping. The expectations of this SEEFOR project were making Rivers state to have steady clean environment and promote healthy environment free of waste-related diseases. SEEFOR in Rivers State was directly under the State Project Coordinating Unit (SPCU) and supervised by the Ministry of Budget and Economic Planning. SEEFOR project has community members involvement as one of the cardinal points 
of action, local contractors were used, and they were also mandated to employ local residents within the state to carry out the activities of refuse collection, road sweeping, desilting and fumigation of drainages. It was an inclusive project that ensures:

1) community participation in decision making at the planning and implementation stage.

2) integration of host community residents.

3) promotion of social inclusion of vulnerable and marginalized group within the locality.

4) avoidance gender bias (it ensures at least 50\% involvement of women); and

5) community members participation in project monitoring

It will be pertinent to say that the overall objective SEEFOR project in Rivers State is to ensure youth employment opportunities through small public works and access to socio-economic services and at same time improve the management of public finance in the state. But embedded in this objective is maintenance of quality environment through public participation, mostly in solid waste management.

\section{SOLID WASTE GENERATION}

Solid waste as construed in this paper are mostly household waste generated in residential area, offices and marketplaces, most prominent categories of solid waste generated in these places are organic waste, paper, plastic bottles and nylon Solid wastes are those range of garbage materials which arises from animal and human activities, that are discarded as unwanted and useless, Leblanc (2020). AlKhatib et al. (2010) pointed out that solid waste generation (SWG) is a problematic issue of concern everywhere in the world, particularly in all urban centers. Such SWG is considered one of the most challenging issues faced by most developing countries that suffer from sever environmental pollution problems caused by the large quantities of SWG. Demirbas (2011) describes waste management as a process by which wastes are gathered, transported and processed before disposal of any remaining residues. Management of these wastes is a critical concern to government all over the world due to relatedness to health of the people and also environmental hygiene and sustainability.

\section{STATUS OF SOLID WASTE MANAGEMENT IN RIVERS STATE}

Solid waste Management is one of the cardinal foci of SEEFOR in Rivers State in other to maintain the quality of the state environment. For solid waste management, SEEFOR mapped out 22 major roads in Rivers State and engaged community women and youths for daily sweeping of the roads, they also carry out routine desilting and fumigation in these areas. For the collection and disposal of the daily generated waste, SEEFOR engaged more than 87 contractors who uses their compactor tractors to collect solid waste that are daily generated at different points of collections approved by RIWAMA in River State, among the routes covered are Ahoada East, Ahoada West, Andoni, Asari Toru, Bonny, Degema, Emohua, Eleme, Ikwerre, Khana, Obio/Akpor, Ogba/Egbema/Ndoni, Opobo/Nkoro, and PortHarcourt Local Government Areas of Rivers State. Special arrangement was also made for streets where the compactors cannot pass through, such areas were provided with waste tricycles. The tricycle operators were mainly youths that were engaged within the locality who are familiar with the terrain of the allocated streets (See Figure 1 and Figure 2 for refuse collection point). The 
collected wastes are carried to approved dumpsite in which Oyigbo, Eleme, Eliozu and Igwuruta. Waste collected from different receptacles and dumpsites in the city of Port Harcourt consisted of $66.6 \%$ volatile solids, $13.5 \%$ fixed solids, $19.1 \%$ liquid and $0.8 \%$ other components (ESMP, 2015). The constitution of the waste generated are mostly organic waste, paper, nylon, plastic containers, and so on. The mean percentage composition of organic waste was $65 \%$, paper $11 \%$ and for nylon $12 \%$. While that of Obio/Akpor which is the most densely populated local government areain Rivers State is $69 \%$ for organic waste, $13 \%$ for paper and $16 \%$ for nylon, (ESMP, 2015).
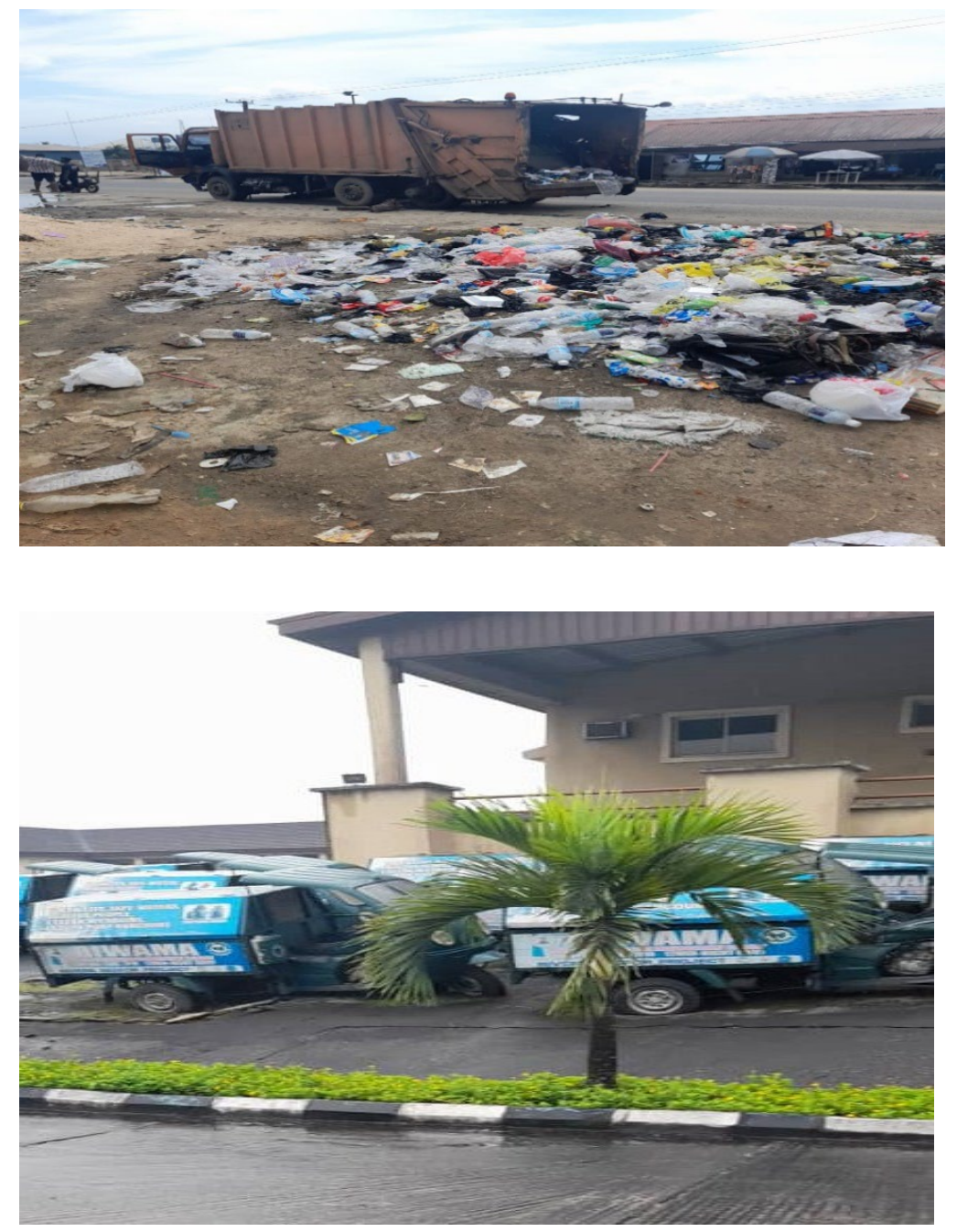

Figure 1 Waste Disposal Compactor Truck

Despite SEEFOR and RIWAMA efforts towards waste management, hips of solid waste are still littered along the streets and walkways in Portharcourt and it environ, most especially areas that close to markets, communities and watersides. This is in line with Okorie and Amadi (2017) observation that residents of Port Harcourt metropolis indiscriminately dispose their household waste along major roads, streets and highway's pedestrian walkway without minding the effect on the environment, their surroundings and health. Liyala (2011) observed that the increased generation of solid waste in urban cities affected dramatically on the sanitary related problems and the basic services such as sanitation facilities, water supply, waste management, and transport infrastructure. 


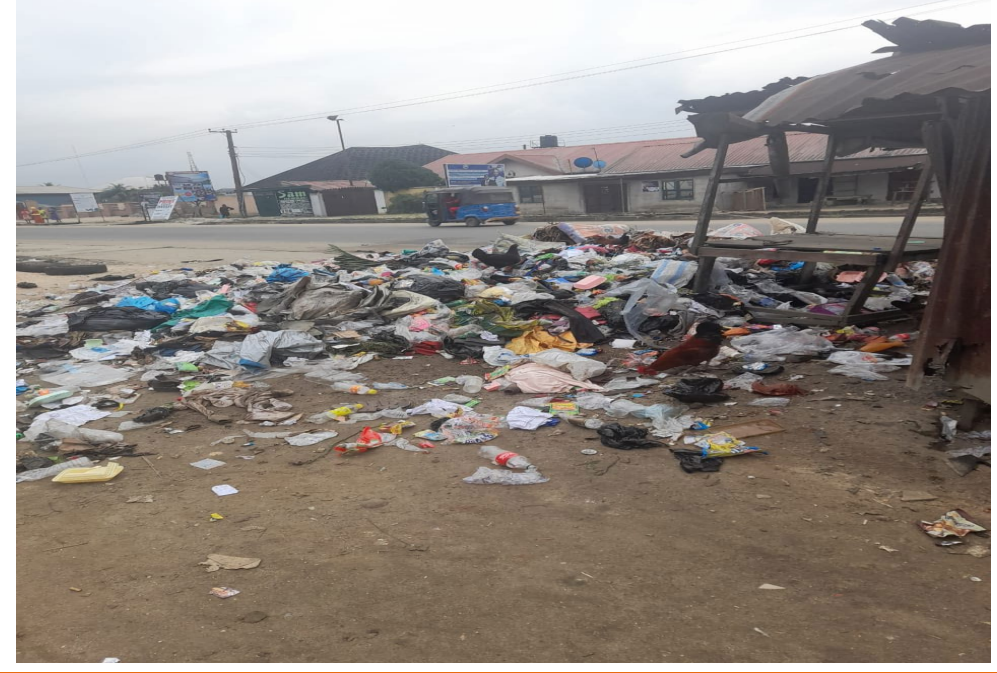

Figure 2 Improper Waste Disposal

\section{INDISCRIMINATE DISPOSAL OF WASTE ALONG MAJOR ROAD IN RIVERS STATE}

Thus, continuous presence of indiscriminate waste disposal in Rivers State call for a change in strategy which will be rooted to attitude and behaviour of individuals towards waste and the environment. Rivers State is one of the states in Nigeria that continually witness influx of people into the state, thereby increasing the population size of the state, 2006 population census show that Rivers State has a population of 5,198,719, in 2015 the population of Rivers State was estimated to be 7 million. United Nation Environment Programme (UNEP, 2018) estimated the increase in global population that are residing in cities to rise $66 \%$ by 2050 , compared to $\sim 54 \%$ residing now. The implication is that 2.4 billion people will be potentially added to the global urban population, and that this will inevitably result in a significant expansion of existing urban environments and lead to the need to create new ones. UNEP (2012) also estimated the material consumption related to cities will augment to $\sim 90$ billion tons by 2050 compared to 40 billion tons in 2010. Washburn et al. (2009) stressed that the estimated projections increase in urban cities population and consumptions will lead to deterioration of liveability challenges related to waste management, scarce resources, air pollution and traffic congestion that cause human health concerns, as well as aging public infrastructure, are some of the problems generated by rapid urbanization.

Presently Rivers State population is projected to be 11 by end of 2021 (National Population commission, NPC, 2021). The continual increase in solid waste generation in Rivers State is as a result of urban growth in towns and communities in the State. Increase in population is usually related to economic status of residents, lifestyles and consumption patterns. This corroborates with Scharfe in Komba (2021) observation that the greater the society's population and material wealth, the greater the quantity and diversity of waste produced. Influx of people into Rivers State due to it urbanization has continue to be the reason for more generation of solid waste by residents and daily generated waste is surpassing safe disposal rate and call for a proactive strategy.

The implication of the above statement is that human being is the epicenter of indiscriminate disposal of waste and defacing the environment through their 
daily waste generation from the teeming population as a result of their poor or I don't care attitude toward waste and the environment at large, This I don't care attitude of people mostly at low cost residential areas and market places toward solid waste implies that they can live comfortably with accumulative heap of solid waste within their neighborhoods. . Attitude according to Ifegbesa (2010) is an important predictor in elucidating intention or behaviour towards solid waste management. However, in other to tackle people's attitude towards waste management, SEEFOR strategies of community members participation in decision making at the planning and implementation stage of waste management need to need to be improved on to include strategies that promotes proper attitudinal change toward solid waste generation and disposal among residents. Residents attitude towards solid waste generation, storage, collection, and disposal in accordance with the best principle of public health and environmental sustainability.

\section{CONCEPT OF ATTITUDE}

Attitude according to Petty and Krosnick (2014) can be defined as feeling about something or the way of thinking in a cooperative or uncooperative behavior. Petty and Wegener (1998, p:3230) pointed out that "attitudes attitude is important because of the fundamental role that individuals' attitudes...play in the critical choices people make regarding their own health and security as well as those of their families, friends, and nations". In view of this, Cohen in Arie et al. (2018), describe attitudes as "determinants of how a person will actually behave in his daily affairs". An attitude according to Hogg and Vaughan (2005), p.150), is "a relatively enduring organization of beliefs, feelings, and behavioral tendencies towards socially significant objects, groups, events or symbols". McLeod (2018) further explained that attitude is structured in three components, which are affective, behavioural and cognitive. Affective component involves a person's feelings or emotions about the attitude object; the behavioural component, is the way the attitude we have influences on how we act or behave, while the cognitive component involves a person's belief/knowledge about an attitude object. The three structure of attitude is also called the ABC model of attitude. Most scholars associate attitude with behaviour, one of such scholars is Allport cited in Arie et al. (2018), who concluded that an attitude reflects a disposition to act. This is also in support of McLeod (2018) observation that the underlying assumptions about the link between attitudes and behavior is that of consistency. That the behavior of a person is often expected to be consistent with the attitudes that he/she hold. This association is called the principle of consistency, this principle has been faulted by scholars because in most cases people's behaviour does not follow the assumption of principle of consistency. People sometimes behave in illogical ways., for example, people take drug despite knowing that drug is dangerous to their mental health. But attitude-behaviour consistency usually exists when there is a strong relation between opinion and action. For example, most people in Nigeria low-income neighbourhood have strong conviction that "dirty no dey kill African man" and that is why they litter their environment with solid waste generated from their homes, this negative attitude towards the environment shows a low attitude-behaviour consistency which is detrimental to environmental protection. Waste littered around surrounding environment are contaminants to the environment and detrimental to environment and health of people. Thus, reducing the impact of or risk associated with the contaminants (waste) through strategies that involve community members or dwellers in Rivers State will promote sustainable city attainment in Rivers State. 


\section{SUSTAINABLE CITY}

A sustainable city is a city that is well planned to address environmental, social and economic problem that are inherent in a typical city through urban planning and city management system. Waste generation is a prominent environmental problem that is related to social and economic life of city dwellers. Increase in population due to urbanization and rural urban migration leads to increase in consumption by dwellers and generation of more waste. Many people migrate daily to River's state due to it urban setting and this has resulted to increase in waste generation from residents and the present strategy. Cities according to Satterthwaite (2010) provide public services such as water and sanitation, health care, education, electricity, emergency services and public recreational areas and government is expected to ensure that such benefits are realised, and to adopt a sustainable framework that encourages the city's growth within ecological limits. Ibri and Krogstie (2019) a sustainable city as a "desired (normative) state in which a city strives to retain a balance (enhancing the physical, environmental, social, and economic systems of the city in line with sustainability over the long run given their interdependence, synergy, and equal importance) of the socio-ecological systems through adopting and executing sustainable development strategies as a desired (normative) trajectory". Haughton and Hunter in Al-Zoabi and Jarrar (2016) viewed a sustainable city as a place where achievements in social, economic and physical development are made to last; which has a lasting supply of the natural resources on which its development depends (using them only at a level of sustainable field); and also maintains a lasting security from environmental hazards which may threaten development achievements. Achieving sustainable cities and communities is the $11^{\mathrm{TH}}$ goal of Sustainable Development Goal and implies that making cities and communities sustainable is of global concern.

Waste is one of the major environmental problems that has adverse effect on sustainable city in which SDG goal 11 also indicated that by 2030, the adverse per capital environmental impact of waste on cities should be reduced. Reduction of adverse impact of waste cannot only be achieved through government efforts such as what RIWAMA is doing presently in Rivers State, members of the community need to be involved for waste management to be sustainable and also to make River State a sustainable city.

\section{INVOLVEMENT OF COMMUNITY MEMBERS IN WASTE MANAGEMENT FOR SUSTAINABLE COMMUNITY/ CITY THROUGH ENVIRONMENTAL EDUCATION}

Negative attitude towards the environment that are exhibited by residents in Rivers State through the indiscriminate waste disposal can be positively reverse through proper strategies. Brown in Swesi et al. (2019) stressed that the attitude of the individual to solid waste management can be positively influenced through education. Debrah et al. (2021) in their study on raising awareness of solid waste management through formal education for sustainability : a developing countries evidence review, stated that education is one of the essential tools to create awareness among people, particularly in developing countries. They further explained that environmental education can increase people's awareness about the environment and its accompanying challenges, it can also increase the expertise necessary to deal with the environmental challenges and promote attitudes, motivations, and commitments to form decisions and take responsible actions. This is support of Tikka et al. (2010) findings in their study on effect of educational 
background on students' attitudes, activity levels and knowledge concerning the environment established that education influences environmental awareness and attitude. In view of this, Di Fabio and Kenny (2018) also pointed out that people's attitudes toward the environment and the type of concern they develop toward it are associated with the degree to which they view themselves as being interconnected with nature. From the above observations, it is pertinent to say that providing proper environmental education to community and city dwellers in Rivers State, most especially those living in low income neighbourhood that possess the attitude of dirty no dey kill African man, thereby littering their surrounding with their daily generated waste need requisite environmental education for attitudinal change, that achieving environmental positive attitude through environmental education will go a long way to supplement RIWAMA waste management strategies and thereby bring about sustainable waste management for attainment of sustainable communities and cities in Rivers State.

\section{ENVIRONMENTAL EDUCATION}

Environmental education any educational programme or activity that designed for recipient to explore environmental issues, engage in problem solving activities which will enable the beneficiaries to take action to improve the environment due to their understanding of environmental issues and acquisition of skills to make informed and responsible decisions. Environmental education provides environmental awareness, knowledge of environment and its associated problems, lead to positive attitudinal change towards the environment among the learners, equip the adult learners with skills of handling environmental issues and promotes the consciousness of participating in activities that help in sustaining the environment.

Environmental education is a learning process that increases people's knowledge and awareness about the environment and associated challenges, develops the necessary skills and expertise to address the challenges, and fosters attitudes, motivations, and commitments to make informed decisions and take responsible action (UNESCO, Tbilisi Declaration, 1978). Tumbaack (2020) asserted that "environmental education described the interrelationships among organisms, the environment and all the factors, which influence life on earth, including atmospheric conditions, food chains, the water cycle etc. It is a basic science about our earth and its daily activities, and therefore, this science is important for everyone". He further stated that the scope of environmental education (EE) as.

1) EE creates awareness among the people to know about various renewable and non-renewable resources of the region. The endowment or potential, patterns of utilization and the balance of various resources available for future

2) EE provides the knowledge about ecological systems and cause and effect relationships.

3) EE provides necessary information about biodiversity richness and the potential dangers to the species of plants, animals and microorganisms in the environment.

4) EE enables one to understand the causes and consequences due to natural and induced disasters (flood, earthquake, landslide, cyclones etc) and pollutions and measures to minimize the effects.

5) EE enables one to evaluate alternative responses to environmental issues before deciding an alternative course of action. 
6) EE enables environmentally literate citizens (by knowing the environmental acts, rights, rules, legislations, etc.) to make appropriate judgments and decisions for the protection and improvement of the earth.

7) EE exposes the problems of over population, health, hygiene, etc. and the role of arts, science and technology in eliminating/ minimizing the evils from the society.

8) EE tries to identify and develop appropriate and indigenous eco-friendly skills and technologies to various environmental issues.

9) EE teaches the citizens the need for sustainable utilization of resources as these resources are inherited from our ancestors to the younger generation without deteriorating their quality.

10) EE enables theoretical knowledge into practice and the multiple uses of environment.

Stapp in Okorie (2021) stated that environmental education is aimed at producing a citizenry that is knowledgeable concerning the biophysical environment and its associated problems, aware of how to help solve these problems, and motivated to work toward their solution. It is based on this assertion that Japan Environmental Education Forum (2000), observed that that achieving the objectives of environmental education requires long-term ongoing education which has incremental targets rather than pressing individuals to action, it is important to gradually develop interest and understanding. The incremental targets are:

Interest: learners need to become familiar and aware of nature or the environment this will enable them to show concern on how littering affects the environment

Understanding; leaners are to learn how nature and society are intertwined, this will enable to understand that littering of waste around their surroundings, streets and walkways is inappropriate.

Action: learners are to take up incremental issues as one's own, and also acting to resolve them this will thus promote participation in actions of sustainable solid waste practices.

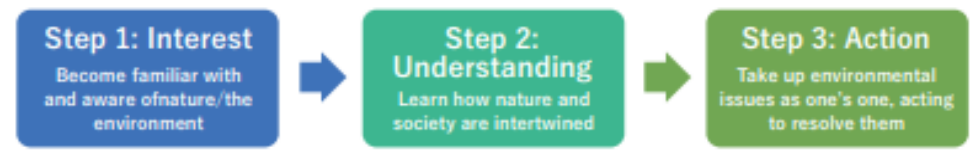

Fig. 4 Incremental targets of environmental education

Applying the incremental targets of environmental education to waste issues yields the following:

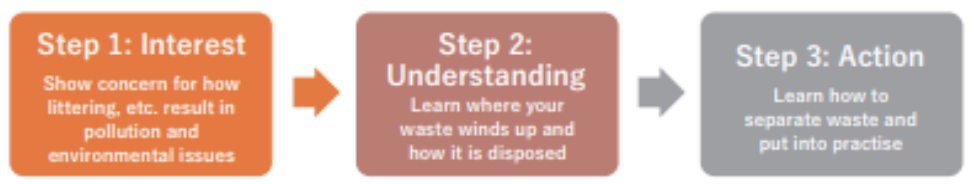

Fig. 5 Incremental targets for waste issues

Figure 3 Incremental Stages of Environmental Education and Targets of Incremental Waste Issues Adapted from Forum (2000) 


\section{WAYS OF UTILIZING ENVIRONMENTAL EDUCATION FOR IMPROVE WASTE MANAGEMENT}

Achieving incremental targets (interest, understanding and action) of EE for waste management for attainment of sustainable communities in Rivers State required promotion of the following positive attitude-behaviour among community dwellers and residents:

1) Rethink: To rethink of the view they have of the environment to understand the choice they make daily towards the environment. For example, making them to carry out audit of waste they generate daily, this enables them to have an idea of areas of their life that cause the most waste

2) Refuse: Refuse to accept plastic bags all the time you make purchase, being more conscious can help change your habits.

3) Reduce: Reducing the number of garbage, food waste, and plastic used in everyday life. Use reusable serving utensils and trays instead of disposable items, swap paper towels, napkins, plates and cup for cloth towels, napkins, reusable plates and cups

4) Re-use: Use material over and over again in its current form not discarding it because you have money to buy the latest design or brand.

5) Re-gift: Instead of throwing away things you no longer need into the environment, you can give it out to other people who may be in need of it.

6) Repair: Before disposing of an item, consider the ways in which it could be repurposed or repaired.

7) Rent: Rent certain things that their usage is sometimes one time instead of buying such items

8) Recycle: Recycle/recovery is the process by which materials otherwise destined for treatment or disposal are collected, processed, and/or remanufactured into the same or different products either onsite or offsite.

9) Rot: turn your food waste and other organics waste $c$ and other organics back into nutrient-rich soil through composting

\section{CONCLUSIONS}

Increase in urban population in River's state, coupled with people negative attitude toward waste disposal contributed to observable increase in waste generation which defeats present RIWAMA efforts. Residents/dweller's attitude toward the environment is also a major contributing factor to their negative environmental behaviour and require a change in strategy that is more environmentally friendly through environmental education. however, raising public awareness of environmental responsibility by practicing proper and sustainable waste management for sustainable community/city is achievable through education. environmental education promotes incremental waste management targets (interest, understanding and action) rather than pressing or forcing individual to action. 


\section{SUGGESTIONS}

The paper suggested that following based on the conclusion:

1) Since attitudes of people towards the environment is related to their environmental behaviour, it is pertinent for human attitude towards the environment be part of environmental education given to individuals from young age.

2) The notion of dirty no dey kill African man is a fallacy that determine most low-income neighbourhood solid waste habbit that need to be debunked through requisite environmental education for attitudinal change.

3) RIWAMA and other agencies responsible for solid waste management, should go beyond packing of waste with trucks and sweeping of roads to educating of the community dwellers/ residents on how to inculcate positive attitude towards environment.

\section{REFERENCES}

Al-Khatib, I.A., Monou, M., Abdul, S.F. Hafez, Q.S., \& Despo, K. (2010). Solid, waste characterization, quantification and management practices in developing countries. A case study Nablus district - Palestine. Retrieved from https://doi.org/10.1016/j.jenvman.2010.01.003

Al-Zoabi, A.Y \& Jarrar, O.M (2016). A sustainable city paradigm: criteria and indicators of efficiency. WIT Transactions on Ecology and The Environment, 204, 143-159. Retrieved from https://doi.org/10.2495/SC160131

Arie W. Kruglanski, Conrad Baldner, Marina Chernikova, Calogero Lo Destro, Antonio Pierro (2018). A new perspective on the attitude-behavior relation : The essential function of goals. Polish Psychological Bulletin 2018, 49(1) 31-39. Retrieved from https://www.researchgate.net/profile/MarinaChernikova/publication/324485349_A_new_perspective_on_the_attitude_ behavior_relation_The_essential_function_of_goals/links/5acfa4b9aca2723 a33469595/A-new-perspective-on-the-attitude-behavior-relation-Theessential-function-of-goals.pdf

Debrah, J.K. ; Vidal, D.G. ; Dinis, M.A.P (2021). Raising awareness on solid waste management through formal education for sustainability: A developing countries evidence review. Recycling, 6, 6. https://doi.org/10.3390/ recycling601000. Retrieved from https://doi.org/10.3390/recycling6010006

Di Fabio, A. ; Kenny, M.E. (2018). Connectedness to nature, personality traits and empathy from a sustainability perspective. Curriculum Psychology. Retrieved from https://doi.org/10.1007/s12144-018-0031-4

Hogg, M., \& Vaughan, G. (2005). Social Psychology (4th edition). London : PrenticeHall.

Ibri, S.E., Krogstie, J. A. (2019). Scholarly backcasting approach to a novel model for smart sustainable cities of the future : strategic problem orientation. City Territ Archit 6, 3. Retrieved from https://doi.org/10.1186/s40410-0190102-3

Ifegbesan, A. (2010). Exploring Secondary School Students' Understanding and Practices of Waste Management in Ogun State, Nigeria.', International Journal of Environmental and Science Education, 5(2), pp. 201-215 Retrieved from https://eric.ed.gov/?id=EJ884419 
Japan Environmental Education Forum (2000). Japanese-style Environmental Education Proposals (New Ed.), Shogakukan.

Katz, D. (1960). Public opinion quarterly, 24, 163 - 204. Retrieved from https://doi.org/10.1086/266945

Komba, T. (2021), "Residents' Perceptions and Attitudes towards Municipal Solid Waste Management Practices in Freetown Central Zone, Sierra Leone.", International Journal of Research in Environmental Science (IJRES), vol. 7, no. 2, pp. 12-27, 2021. Available: DOI: Retrieved from https://doi.org/10.20431/2454-9444.0702002

LaPiere, R. T. (1934). Attitudes vs. Actions. Social Forces, 13, 230-237. Retrieved from https://doi.org/10.2307/2570339

Leblanc, R. (2020). An introduction to solid waste management. Assessed online from Retrieved from https://www.thebalancesmb.com/an-introduction-tosolid-waste-management-2878102.

Liyala, C.M. (2011). Modernizing solid waste management at municipal level: Institutional arrangements in urban centers of East Africa. Environmental Policy Series. Wageningen University, The Netherlands. Retrieved from https://doi.org/10.3920/978-90-8686-745-5

McLeod, S. A. (2018). Attitudes and behavior. Simply Psychology. Retrieved from www.simplypsychology.org/attitudes.html

Petty, R.E. \& Krosnick, J.A. (2014). Attitude strength: Antecedents and consequences. Psychology Press. Retrieved from https://doi.org/10.4324/9781315807041

Stapp, William B., Ed. ; Cox, Dorothy A., Ed. (1969). The Concept of Environmental Education. Journal of Environmental Education, 1(1), 30-31. Retrieved from https://doi.org/10.1080/00139254.1969.10801479

Swesi, A.E.M, Mallak, S.K \& Tendulkar, A (2019). Community attitude, perception and willingness towards solid waste management in Malaysia, Case Study. Journal of Wastes and Biomass Management, 1(1), 09-14. Retrieved from https://doi.org/10.26480/jwbm.01.2019.09.14

Tikka, P.M. ; Kuitumen, M.T. ; Tynys, S.M. (2010). Effect of Educational Background on students' attitudes, activity levels and knowledge concerning the Environment. Journal. Environment Education, 31, 12-19. Retrieved from https://doi.org/10.1080/00958960009598640

Tumbaack (2020). Environmental Education : Meaning, Importance and Scope. Assessed online fromhttps://onlinenotebank.wordpress.com/2020/02/06/environmentaleducation meaning-importance-and-scope/.

UNEP (2018). The Weight of Cities-Resource Requirements of Future Urbanization. Paris : International Resource Panel Secretariat.

United Nation (UN, 2018). The Sustainable Development Goals Report. Available online at : https://www.un.org/development/desa/publications/thesustainable-development-goals-report-2018.html.

United Nation Environment Programme (UNEP, 2012). Sustainable, Resource Efficient Cities-Making it Happen. Paris : United Nations Environment Programme Division of Technology, Industry and Economics.

Washburn, D., Sindhu, U., Balaouras, S., Dines, R. A., Hayes, N., and Nelson, L. E. (2009). Helping CIOs understand "smart city" initiatives. Growth 17, 1-17 